\title{
Analysis of the Addition of $C M C$ to Biodegradable Plastics from Banana Hump
}

\author{
Chairul Amni $^{* 1}$, Ismet $^{2}$, Irmayanti ${ }^{3}$, Joli Supardi ${ }^{4}$, Miftahurrahmah $^{5}$ \\ ${ }^{1.2}$ Department of Industrial Engineering, Faculty of Engineering, \\ Universitas Serambi Mekkah, Banda Aceh, Indonesia \\ ${ }^{3}$ Department of Agricultural Industrial Engineering, Faculty of Agriculture, \\ Universitas Serambi Mekkah, Banda Aceh, Indonesia \\ ${ }^{4}$ Department of Mechanical Engineering, Teuku Umar University, Meulaboh, Indonesia \\ ${ }^{5}$ Department of Chemical Engineering, ATI Polytechnic, Padang, Indonesia
}

*Corresponding Author: chairulamni1@gmail.com

\begin{abstract}
The use of banana hump flour as a raw material for making biodegradable plastic is an alternative to using banana starch plastic in an effort to reduce plastic waste. Bananas contain $66 \%$ carbohydrates, protein, water and essential minerals. To get biodegradable plastic, starch is added along with CMC (carboxy methylcellulose), glycerol and citronella oil as anti-bacterial and antioxidant. In this research, a research was conducted on the manufacture of biodegradable plastic mixture of starch, carboxy methyl cellulose (CMC), glycerol as a plasticizer and citronella oil by modifying CMC, glycerol and citronella oil. This study includes two variables, namely fixed variables and variable variables. Fixed variables include starch concentration with water 1:5, stirring speed $100 \mathrm{rpm}$ and starch gelatinization temperature $70 \mathrm{oC}$, while variables including CMC concentration include levels $(5.5 ; 6.5$; and 7.5) \% (w/w), Citronella oil concentrations included (15; 20; and 25) \% (w/v), and glycerol concentrations included $(25 ; 35$; and 45$) \%(w / v)$. This study aims to determine the effect of adding CMC citronella oil and glycerol as a plasticizer to the mechanical properties, morphology, and biodegradability tests, as well as the antioxidant activity of the resulting plastic. The results of this study indicate that biodegradable plastic has a tensile strength value of $0.210 .38 \mathrm{kgf} / \mathrm{mm} 2$; elongation value between 16.3-54.20\%; Morphological examination showed that the surface of the plastic was smooth and the plastic completely decomposed in the soil within 27 days.
\end{abstract}

Keywords: Biodegradable plastic, CMC, banana starch.

\section{Introduction}

Plastic is a popular packaging material and is widely used throughout the country, making up most of the components of basic necessities, ranging from electronic equipment, household appliances, office furniture to food. Plastic products and beverages use plastic for packaging because they are light, strong, easy to shape and affordable (Mahalik and Nambiar 2010). Not only in the industrial sector, plastic packaging is also widely used by retailers, traditional traders and households. According to the Indonesian Plastic and Aromatic Olefin Industry Association (INAPLAS), plastic consumption in Indonesia in 2015 reached 17 $\mathrm{kg} / \mathrm{capita} /$ year. While Indonesia's population in the first half of 2017 was around 261 million, the amount of plastic used nationally reached 4.44 million tons. Excessive use of plastic has a negative impact on environmental sustainability (Tokiwa et al. 2009), due to the difficulty of decomposition, the accumulation of plastic waste causes environmental pollution. 
According to the Ministry of Environment and Forestry (2016), the problem of plastic waste in Indonesia is already worrying. Besides China, Indonesia is the country that dumps the most plastic waste into the sea, littering clogs waterways, and even piling up in estuaries, causing flooding. Plastic buried in the ground is also difficult to decompose. The synthetic polymers that make up most plastics break down in tens or even hundreds of years. If burned, plastic will produce carbon emissions that pollute the environment (Gironi and Piedmont 2011) This poses a big problem for the environment and public health, so research and technology owners need to do research to produce new materials that can and are easily biodegradable. of course. The alternative is to use biodegradable plastic.

Plastic biodegradable is a plastic that can be explained naturally by microorganisms. Biodegradable plastics can be made from various materials with relatively high starch content (Parra et al., 2004). For this reason, researchers here will use starchy raw materials from agricultural residues, namely banana weevil. So far, banana weevil is still used as animal feed, so it is appropriate to use this waste as a source of starch to be used as a biodegradable plastic processing material.

Utilization of banana weevil starch as a raw material for making biodegradable plastic is an alternative to using banana weevil waste and reducing plastic waste. Banana hump which contains $66 \%$ carbohydrates, protein, water and essential minerals . In addition to starch, several other ingredients are added to the process of making biodegradable plastics to produce high - quality plastics such as carboxymethylcellulose (CMC), essential oils and glycerol as a plasticizer. Carboxymethylcellulose (CMC) is one of the most commonly used cellulose derivatives in the production of edible films . CMC is a linear, long chain, water soluble, highly viscous and non-toxic anionic polysaccharide . CMC has many applications as an ingredient in food, medicine, adhesives, lubricants, pesticides, fabrics, ceramics, cement, paper and coatings (Alireza et al., 2014). Biodegradable plastic with the addition of antioxidant antimicrobial compounds is packaging that can reduce, prevent or slow down the growth of pathogenic microorganisms in food packaging and packaging materials. Antimicrobial and antioxidant ingredients used in food applications include essential oils , bacteria, enzymes, alcohols and fatty acids. Essential oils are produced from certain parts of plant tissues such as roots, stems, bark, leaves, flowers or seeds, obtained by steam distillation (Harris, 1987). In this research, a research was conducted on the manufacture of biodegradable plastic mixture of starch, CMC, glycerol as a plasticizer and citronella oil by modifying CMC, glycerol and citronella oil.

\section{Method}

The main ingredient in this research is Wak banana weevil starch. Furthermore, the main ingredient is added CMC with a concentration of $5.5 \%(\mathrm{w} / \mathrm{w}) ; 6.5 \%(\mathrm{w} / \mathrm{w})$ and $7.5 \%(\mathrm{w} / \mathrm{w})$, citronella oil was added as an antimicrobial and antioxidant compound with a concentration of $15 \% \mathrm{w} / \mathrm{v}, 20 \% \mathrm{w} / \mathrm{v}$; and $25 \% \mathrm{w} / \mathrm{v}$ and added glycerol as a plasticizer with a concentration of $25 \% \mathrm{w} / \mathrm{v}, 35 \% \mathrm{w} / \mathrm{v}$ and $45 \% \mathrm{w} / \mathrm{v}$. Making biodegradable plastic is done using the blending method, namely by mixing all the ingredients into one into an Erlenmeyer glass. The mixture was heated while stirring using a hot plate and a magnetic stirrer to a temperature of $(70)^{\circ} \mathrm{C}$. Printing is done by pouring the material on the polyethylene base mold evenly and drying at room temperature for 24 hours. The arrangement of treatment combinations can be seen in Table 1. 
Table 1 Combination of Treatments

\begin{tabular}{|c|c|c|c|c|c|}
\hline \multirow{2}{*}{ No } & \multirow{2}{*}{$\begin{array}{c}\text { Concentration } \\
\text { CMC }\end{array}$} & \multirow{2}{*}{$\begin{array}{l}\text { Oil Concentration } \\
\text { Lemongrass }\end{array}$} & \multicolumn{3}{|c|}{ Concentration of Added Glycerol } \\
\hline & & & $\begin{array}{c}\mathrm{G} 1: 25 \% \\
\mathrm{~b} / \mathrm{v}\end{array}$ & $\mathrm{G} 2: 35 \% \mathrm{~b} / \mathrm{v}$ & G3: $45 \% \mathrm{~b} / \mathrm{v}$ \\
\hline \multirow{3}{*}{1} & \multirow{3}{*}{$\mathrm{C} 1: 5.5 \% \mathrm{w} / \mathrm{w}$} & $\mathrm{S} 1: 15 \% \mathrm{~b} / \mathrm{v}$ & C1S1G1 & C1S1G2 & C1S1G3 \\
\hline & & $\mathrm{S} 2: 20 \% \mathrm{~b} / \mathrm{v}$ & C1S2G1 & $\mathrm{C} 1 \mathrm{~S} 2 \mathrm{G} 2$ & C1S2G3 \\
\hline & & $\mathrm{S} 3: 25 \mathrm{gr} b / \mathrm{v}$ & C1S3G1 & C1S3G1 & C1S3G3 \\
\hline \multirow{3}{*}{2} & \multirow{3}{*}{$\mathrm{C} 2: 6.5 \% \mathrm{w} / \mathrm{w}$} & $\mathrm{S} 1: 15 \% \mathrm{~b} / \mathrm{v}$ & C2S1G1 & $\mathrm{C} 2 \mathrm{~S} 1 \mathrm{G} 2$ & $\mathrm{C} 2 \mathrm{~S} 1 \mathrm{G} 3$ \\
\hline & & $\mathrm{S} 2: 20 \% \mathrm{w} / \mathrm{v}$ & C2S2G1 & $\mathrm{C} 2 \mathrm{~S} 2 \mathrm{G} 2$ & $\mathrm{C} 2 \mathrm{~S} 2 \mathrm{G} 3$ \\
\hline & & $\mathrm{S} 3: 25 \% \mathrm{w} / \mathrm{v}$ & $\mathrm{C} 2 \mathrm{~S} 3 \mathrm{G} 1$ & $\mathrm{C} 1 \mathrm{~S} 3 \mathrm{G} 2$ & $\mathrm{C} 2 \mathrm{~S} 3 \mathrm{G} 3$ \\
\hline \multirow{3}{*}{3} & \multirow{3}{*}{$\mathrm{C} 3: 7.5 \% \mathrm{w} / \mathrm{w}$} & $\mathrm{S} 1: 15 \% \mathrm{~b} / \mathrm{v}$ & C3S1G1 & $\mathrm{C} 3 \mathrm{~S} 1 \mathrm{G} 2$ & $\mathrm{C} 3 \mathrm{~S} 1 \mathrm{G} 3$ \\
\hline & & $\mathrm{S} 2: 20 \% \mathrm{~b} / \mathrm{v}$ & C3S2G1 & $\mathrm{C} 3 \mathrm{~S} 2 \mathrm{G} 2$ & C3S2G3 \\
\hline & & $\mathrm{S} 3: 25 \% \mathrm{~b} / \mathrm{v}$ & C3S3G1 & C3S3G2 & C3S3G3 \\
\hline
\end{tabular}

Manufacture Plastic Biodegradable of Wak Wheat Banana starting from dissolving starch banana bananas with $50 \mathrm{ml}$ of distilled water in glass chemistry and stirred for 25 minutes. After the mixture is homogenized, the starch solution is put into a beaker which is placed on an electric stove. The purpose of using an electric stove is to speed up the reaction by increasing the temperature. The purpose of using a magnetic stirrer is to prevent starch formation during heating and to help distribute heat more evenly. Starch was heated at $70^{\circ} \mathrm{C}$ for 20 minutes. Then add plasticizer (glycerol), CMC and citronella oil to the core starch of the banana cob. The purpose of adding glycerol and $\mathrm{CMC}$ is to give elastic properties to banana stem starch. When adding glycerol, CMC and citronella essential oil, it is necessary to stir the starch continuously for 15 minutes to avoid clumping and accelerate the homogenization of the mixture between starch and glycerol, CMC and citronella essential oil . Then the cup is removed from the electric stove. After the starch solution has been removed, the starch solution should be stirred continuously at an ambient temperature of $25-30{ }^{\circ} \mathrm{C}$ for 30 minutes to maintain consistency. After the starch solution has formed and the temperature of the starch solution is normal, the solution is poured onto a $1 \mathrm{~mm}$ thick glass sheet with tape around the edges. The purpose of using masking tape is to prevent the starch solution from spilling over the edge of the glass. The starch solution should be poured slowly. The thin film formed on the glass was placed in an oven at $70^{\circ} \mathrm{C}$ and left for 4 hours to harden and dry. The dried thin layer is removed from the glass by gently opening it with a sharp razor blade so that it can be removed from the pouring glass. The plastic was transferred to desiccators and stored for 24 hours in a place protected from direct sunlight. The biodegradable plastic produced was tested for mechanical properties such as tensile strength and elongation using an autograph. The biodegradability test aims to determine how long it takes for biodegradable plastic to decompose in the soil.

\section{Results and Discussions}

\section{Pull-out Test (tensile strength)}

Mechanical tests carried out on this biodegradable plastic include a tensile test and the 
percentage of elongation at break. This test is performed using a tool called an Autograph. This test is intended to determine the strength of the plastic due to the tensile force applied to the plastic. Figures 3.1, 3.2 and 3.3. showed the effect of concentration of $\mathrm{CMC}$ and citronella essential oil with the addition of $25 \%, 35 \%$ to $45 \%$ glycerol plasticizer on the tensile strength of biodegradable plastics.

The higher the $\mathrm{CMC}$ concentration, the higher the tensile strength value. This increase was due to the presence of hydrogen bonds between the hydroxyl $(\mathrm{OH})$ groups of starch and the hydroxyl $(\mathrm{OH})$ and carboxyl $(\mathrm{COOH})$ groups of $\mathrm{CMC}$. Hydrogen bonding increases the strength of the material, so the addition of $\mathrm{CMC}$ will increase the tensile strength . The resulting tensile strength value when added glycerol is of $0.25 \mathrm{kgf} / \mathrm{cm} 2$ to $0.38 \mathrm{kgf} / \mathrm{cm} 2$. CMC can form colloidal dispersions and increase the viscosity so that the suspended particles will be retained in the system and not deposited by gravity (Potter and Norman, 1986). CMC can prevent protein deposition at the isoelectric point and increase viscosity, due to the meeting of the CMC carboxyl group with a positively charged protein group (Fardiaz, 1986). At a concentration of 5.5\% CMC, from $6.5 \%$ to $7.5 \%$ the value of the tensile strength of the plastic increased. However, this interpretation does not apply to two samples at 7.5\% CMC, namely samples C3S2G1 and C3S3G1This is because the process of mixing the heterogeneous can cause molecular distribution of plastic components that are not evenly distributed, so that the resulting material does not have a load carrying capacity that is good

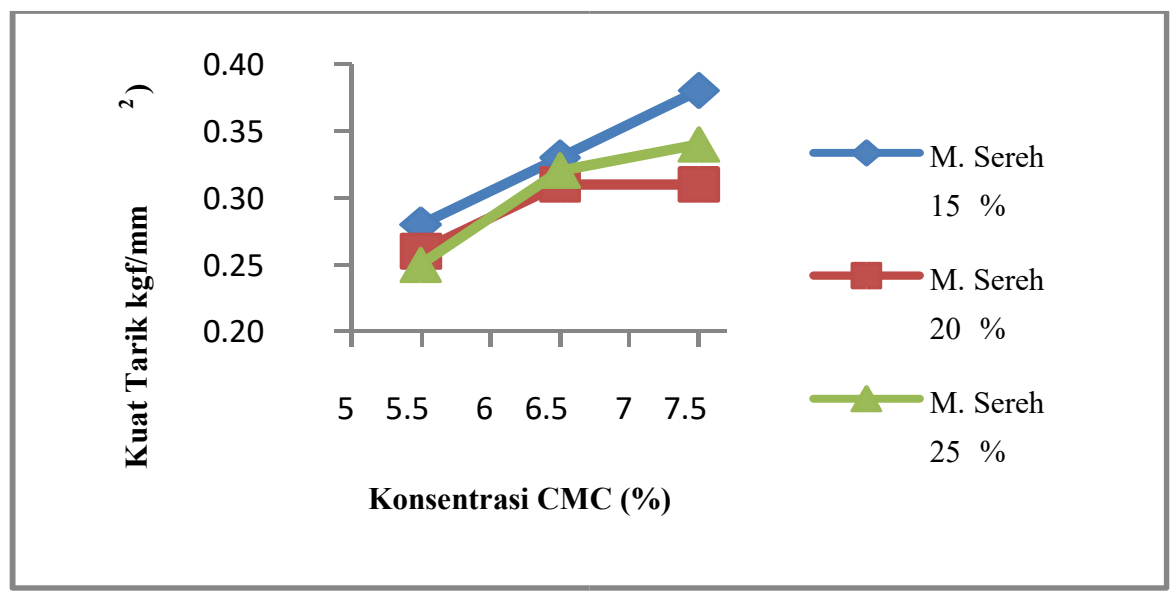

Figure 1. Effect of concentration of CMC and citronella oil on the tensile strength of biodegradable plastic with the addition of $25 \%$ glycerol.

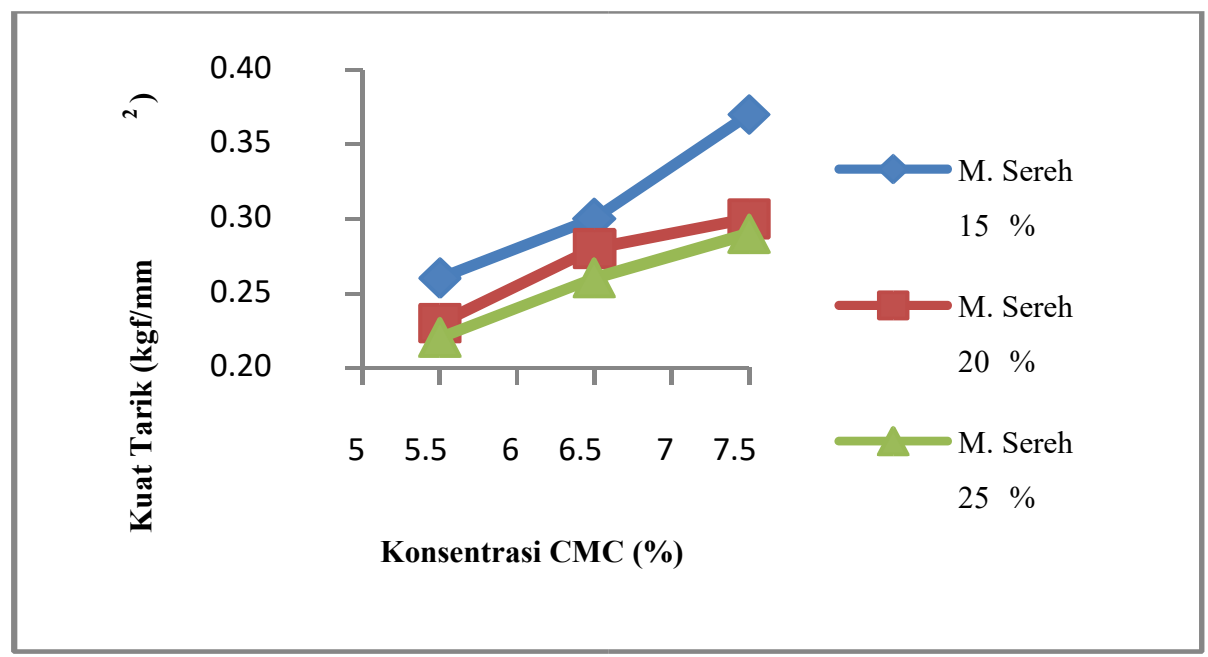

Figure 2. Effect of concentration of CMC and citronella oil on the tensile strength of biodegradable plastic with the addition of $35 \%$ glycerol. 


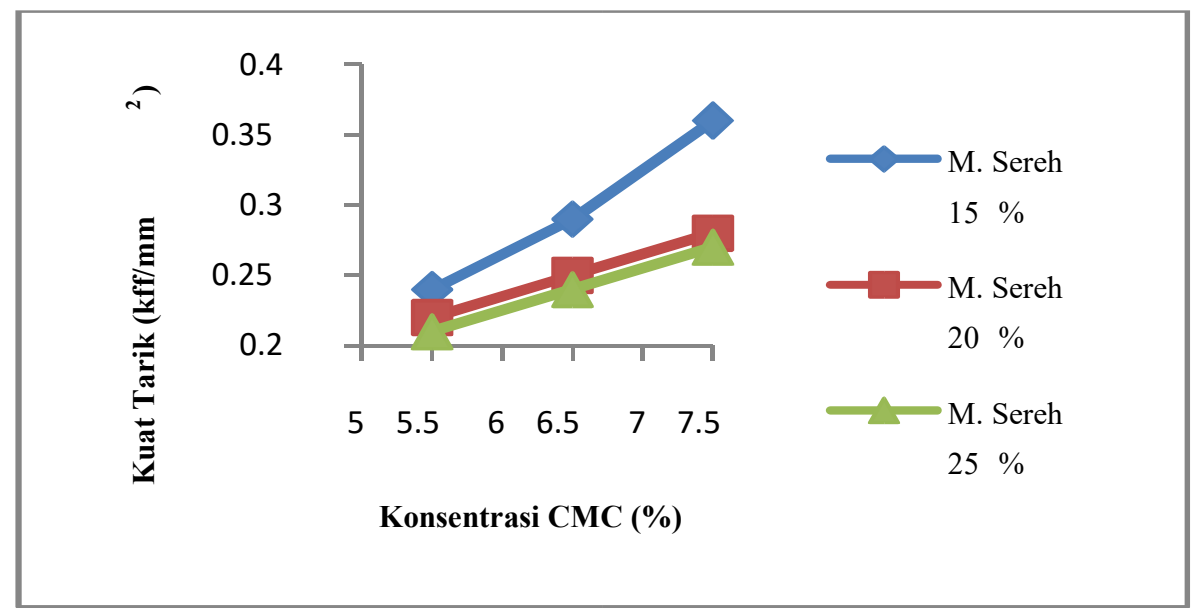

Figure 3. Effect of concentration of CMC and citronella oil on the tensile strength of biodegradable plastic with the addition of $45 \%$ glycerol

From the three graphs it can be seen that the effect of adding lemongrass essential oil to the tensile strength of biodegradable plastic, the higher the concentration of lemongrass essential oil added, the value of the tensile strength tends to go down. Indeed, the addition of antimicrobial and antioxidant compounds in biodegradable plastics is known to affect the mechanical properties, inhibitory strength and optical properties of the formed films, where the degree of influence depends on the type of material formed. Materials extracted from plant products often affect the color and clarity (opacity) of biodegradable plastics (An et al., 1998; Hong et al., 2000). The concentration of citronella essential oil resulted in the highest tensile value found at a concentration of $15 \%$. However, this explanation does not apply to the two samples that were supplemented with $25 \%$ lemongrass essential oil, namely samples $\mathrm{C} 2 \mathrm{~S} 3 \mathrm{G} 1$ and $\mathrm{C} 3 \mathrm{~S} 3 \mathrm{G}$, because at these concentrations there was an increase in the tensile strength value. This is because the process of mixing the heterogeneous could cause oil distribution of essential lemongrass unevenly on the plastic component, as oil volatile lemongrass is hydrophobic so that the process of mixing is not perfect. The comparison of the three images above shows the effect of adding $25 \%$ glycerol, $35 \%$ plasticizer to $45 \%$ on the tensile strength of biodegradable plastic. The higher the glycerol concentration, the lower the tensile strength value. This is because increasing the concentration of plasticizer will reduce hydrogen bonding in the film, thereby increasing flexibility, with increasing ductility, the tensile strength of the film will be smaller as a result the film becomes more flexible, softer and more flexible in size. Therefore, the tensile strength tends to decrease (Krochta, 1994). In addition, Mustika (2006) added that increasing water content and concentration of hygroscopic plasticizer can make the film more polar so that the resulting film has a low tensile value.

Sample treatment with a concentration of $7.5 \% \mathrm{CMC}, 15 \%$ citronella oil and $25 \%$ glycerol (C3S1G1) gave the highest tensile strength value of $0.38 \mathrm{kgf} / \mathrm{mm} 2$. While the concentration of CMC 5.5\%, lemongrass essential oil $25 \%$ and glycerol $45 \%$ (C1S3G3) resulted in the lowest tensile value of $0.21 \mathrm{kgf} / \mathrm{mm} 2$.

\section{Biodegradability Test}

In this study, biodegradability testing was carried out to find out how long the plastic produced decomposes in the soil with the help of microorganisms that naturally exist in the 
soil. The longest treatment that completely degraded in the soil was $\mathrm{C} 3 \mathrm{~S} 2 \mathrm{G} 3$ (CMC 7.5\%, citronella oil 20'n glycerol 45\%), C3S3G1 (CMC 7.5\%, citronella oil $25 \%$ and glycerol).25\%), C3S3G2 (CMC 7.5\%, citronella essential oil 25\% glycerol 35\%) and C3S3G3 (CMC 7.5\%, citronella essential oil 25\% glycerol 45\%). Of the four samples, it took the longest to decompose in the soil because the concentration of CMC used was $7.5 \mathrm{n}$, the concentration of citronella essential oil $25 \%$ was the highest. The four samples took 28 days to fully decompose. This is because biodegradable plastic with the highest addition of CMC greatly affects the durability of the plastic, and citronella essential oil acts as an anti-bacterial agent. The more $\mathrm{CMC}$ added, the slower the bacteria degrade the polymer chains. In contrast, the levels of $\mathrm{CMC}$ and oils essential lowest lemongrass, termination of polymer chains of bacteria in the soil over samples showed that the surface of the plastic biodegradable produced very fine, only on the image of the three levels of magnification are formed white spots that is $100 \mathrm{X}, 1000 \mathrm{X}$ and $1200 \mathrm{X}$.

The treatment with the highest concentration of CMC and citronella oil required a maximum of 27 days to completely decompose. The addition of citronella oil into biodegradable plastic gave a positive result that the higher the content of citronella oil was added, the longer the microorganisms grew and started the browning reaction. The discussion of the results of research and testing obtained is presented in the form of theoretical descriptions, both qualitatively and quantitatively. Experimental results should be displayed in the form of graphs or tables. For charts can follow the format for diagrams and pictures.

\section{Conclusions}

The higher the concentration of $\mathrm{CMC}$, the higher the tensile value, while the higher the concentration of glycerol the lower the tensile value, and the addition of the concentration of lemongrass essential oil also affects the tensile value, namely when the concentration of lemongrass essential oil is added more, the tensile strength tends to increase and decrease at biodegradable plastic. Elongation test showed that the higher concentration of $\mathrm{CMC}$ and oils essential citronella, the lower the rate of elongation of plastic biodegradable, whereas the higher the concentration of glycerol were added, the higher the elongation were produced.

\section{Acknowledgments}

The author would like to thank RISTEKDIKTI for providing financial support for this study.

\section{References}

Alireza D., Vadood, R., Hedayat, H., Seedeh, S., Bruce, G., Koandokht., Mansour, K, and Ramin K. 2014. Antioxidant and Antimicrobial Carbocymethyl Cellulose Films Containing Zataria multiflora essential oil. Research Department, International Branch, Shahid Beheshti University of Medical Sciences, Tehran, Iran.

An, D., Hwang, Y., Cho, S., and Lee, D., 1998. Packaging of Fresh Curled Lettuce and Cucumber by Using Low Density Polyethylene Films Impregnated with Antimicrobial Agents . Journal of the Korean Society of Food Science and Nutrition. 
Bourtoom, T. 2008. Plasticizer Effect On The Properties Of Biodegradable blend film from rice starch-chitosan. Songklanakarin Journal Of Science and Technology. 30(1): 149-165.

Fardiaz, S. 1986. Food Microbiology. PT. Gramedia Pustaka. Jakarta.

Farida. SP (2009). The Role of Glycerol as a Plasticizer in Corn Starch Film With Corn Cob Fine Powder Filler. Thesis University of North Sumatra, Medan.

Guenther, E. 1987. The Essential Oils. Essential Oils, translation of Ketaren, subject: Kitchen Lemongrass. University of Indonesia Press. Jakarta.

Harris, R. 1987. “ Essential Oil Plants”, Self-Help Spreader, Jakarta.

Hong, SI, Park, JD, and Kim, DM 2000. Antimicrobial and Physical Properties of Food Packaging Films Incorporated with Some Natural Compounds. Food Science. Biotechnol.

Krochta, JM, Balwin, EA and Carriedo, MON 1994. Edible Coating and Film to Improve Food Quality. Technomic Publishing, Co.,. Lancaster.

Mustika, R. 2006. The Effect of Starch To Water Ratio And Concentration Of Glycerol (Plasticizer) On Physical Properties Of Edible Film Made From Cassava Starch (Manihot Esculenta). Essay. Syiah Kuala University, Banda Aceh.

Parra, DF, Tadini, CC, Ponce, P., and Lugao, AB 2004. Mechanical Properties And Water Vapor Transmission In Some Blends of Cassava Starch Edible Films. Carbohydrate Polymers. Potter W. and Norman, N. 1986. Food Science. The AVI Publishing Co., Inc. Westport, Connecticut

Senny. W., Dewi K., Yuni. TN (2012). Effect of Addition of Sorbitol and Potassium Carbonate to Characteristics and Biodegradation Properties of Banana Peel Starch. Unsoed, Purwakerto.

Yasni, S. 2013. Processing Technology and Utilization of Spice Extractive Products . IPBPress, Bogor. 